\title{
9 CENAS, ALGUMAS OBS-CENAS, DA RUA
}

Robert Moses Pechman ${ }^{\star}$

\section{ReSUMo}

Importa aqui tomar o acontecimento urbano como sintoma da cidade. Mas de que sofre a cidade? De excesso de individualismo e do escasseamento da vida pública na rua. Mas se o que caracteriza a cidade é o acolhimento do Outro, que se desdobra em convivialidades e em sociabilidades, como podemos pensar numa cidade sem que a questão da hospitalidade venha à tona? À propósito dessa contradição entre cidade e individualismo e privativismo e hospitalidade, me ponho a observar nossas ruas e a divisar certas cenas urbanas, depreendendo dai o que essas cenas podem nos contar de um ethos citadino. E, sim, elas nos contam muitas coisas de uma nova paisagem urbana/humana que insiste em desmanchar a imagem do acolhimento como a cena primordial da cidade, impondo sua obscena verdade, sua cena obs-cena.

Palavras-chave: rua; esfera pública; sociabilidade; acontecimento urbano.

\section{SCENES, SOME OBSCENES, OF THE STREET}

\begin{abstract}
This essay takes the event urban as symptom of the city. What is the suffering of the city? Excess of individualism and the weakness of public life. But if what characterizes the city is the shelter of the Other with sociability, can we think a city without the question of the hospitality? The contradiction between city and individualism, and privacy and hospitality, I observe in our streets, from certain urban scenes, inferring from there what these scenes can tell us of the ethos of the city. They show to many things of a new urban landscape/human. A landscape that insists on disarranging the image of the shelter as the central scene of the city, imposing its obscene truth, its obscene scene.
\end{abstract}

Keywords: street; public scen; sociability; event urban.

\footnotetext{
^ Historiador. Doutor em História pela Universidade Estadual de Campinas. Professor adjunto da Universidade Federal do Rio de Janeiro. Endereço: Universidade Federal do Rio de Janeiro. Predio da Reitoria, sala 543 - Cidade Universitaria - Ilha do Fundão. CEP: 21949-900 - Rio de Janeiro, RJ - Brasil.

E-mail: betuspechman@hotmail.com
} 
Todos os afetos estão na cidade. Ódios, paixões, vergonhas, compaixões, ressentimentos, desejos. Quanto mais a cidade puder absorver esses afetos, mais densamente humana ela vai-se tornando. E quanto mais complexos forem esses afetos e tanto mais variada a rede de relações humanas e sociais, tanto maior a elaboração será necessária para a decodificação de seu sistema de valores e à sua representação. Assim, felizes ou infelizes, pouco importa dividi-las nessas duas categorias, o que conta mesmo é se as cidades conseguem dar forma aos desejos ou se certos desejos conseguem cancelá-la.

Trata-se, aqui,de investigar, em diferentes representações da cidade, como esta responde às diferentes afetações que são experimentadas em seu cotidiano. Tal resposta concerne, pois, à permissividade da cidade quanto à experiência afetiva, individual ou coletiva e sua potência de ser uma ponte ou um obstáculo para tais afetos. Nesse sentido, vamos tomar a cidade não enquanto relações de produção, mas no plano da produção de relações (PORTELLA, 1995, p. 109), no qual os desejos compõem os fios da tessitura urbana. Estamos diante, portanto, do que Benjamim chamou de porosidade, ou seja, a cidade se deixa contaminar pelos afetos e estes se deixam invadir pelo espírito da urbe. Assim, circulando pela cidade, esses sentimentos se alastram pelas ruas, inundando-as e dando forma aos acontecimentos, na mesma medida em que também afetam os indivíduos.

De poros abertos a cidade produz encontros que se traduzem, seja em convivialidades, seja em eróticas. Mas quando esses poros se fecham é a violência e o silêncio que se impõem, pois se o sujeito não pode exprimir seu direito à vida urbana, se o indivíduo não pode colocar em cena seu desejo e é obrigado a cancelar suas paixões, ele vai extrair seu direito à cidade sem o efeito narcotizante de qualquer anestesia. E isso, com certeza, vai doer muito na cidade.

Nesse sentido, vou tomar a rua como uma espécie de lugar de concentração do acontecimento urbano para analisar de que forma a porosidade da cidade movimenta os encontros e os afetos deles decorrentes e como aqueles e estes se materializam em cenas urbanas. Ora, por acontecimento urbano estou entendendo mais do que uma simples irrupção da novidade espetacular, própria da cotidianidade, no tecido da cidade. Por acontecimento urbano, entendo aquilo que vem do cotidiano, mas que se articula com o repertório da cidade, ou seja, aquilo que cai no imaginário da cidade e passa a fazer parte das histórias que a cidade se conta. Melhor dizendo, é acontecimento urbano aquilo que ao cair em solo urbano germina e floresce, se legitimando enquanto fato urbano e passando a fazer parte do repertório do sujeito a cada experiência em que ele é convidado a mobilizar sua subjetividade, que está completamente entrelaçada às "objetividades" da vida pública. Portanto, aquilo que possa parecer banal e ocasional nas cenas que descrevo abaixo pode já estar apontando para uma nova maneira de ser na cidade e, também, como uma nova maneira de ser da cidade, pois a vida pública, mas também a experiência da subjetivação, transformam-se a cada vez que elas são confrontadas pelo imaginário. 
Tentando acompanhar o ritmo vertiginoso da rua e a proliferação dos acontecimentos urbanos, me pareceu, então, que a melhor maneira de apresentar minha percepção da experiência urbana pudesse ser a partir de cenas que, curtas e concisas - quase que num ritmo de videoclipe -, pudessem traduzir a inconsistência de uma sociabilidade onde a rua é cada vez mais representada, numa espécie de metonímia, como a inviabilidade da cidade. Não se espante o leitor pois, com o ritmo e com os cortes na narrativa dessas cenas urbanas que estou propondo. Elas são mesmo recortes que se encerram em si e o leitor será desafiado a nelas ver a banalidade a que está se reduzindo o acontecimento urbano e a própria cidade; mas elas podem ser também fragmentos de uma narrativa na qual ao fim, reencontramos a cidade e seu ethos.

Enquanto o cenário é montado, detenhamo-nos, brevemente, no imaginário sobre a rua observando de que forma o drama urbano vem sendo contado.

Se percorrermos a história da pintura, a partir do século XVIII, se enveredarmos pela literatura do século XIX, se adentrarmos o cinema do século XX e se espreitarmos a publicidade do século XXI, verificaremos como a rua vai ser tematizada pelo viés da desordem, ou seja, será vista como lugar da arruaça. Curiosa essa palavra que aponta para a desordem e carrega consigo a própria palavra rua. Ou seja, se arruaça vem de rua não pode restar dúvidas que a rua sempre evocou algo da natureza do conflito, da confusão, da desordem; algo da qualidade do externo, do público, do mundano, do mundo; algo da ordem popular, plebeia, vulgar. Rua há sempre de lembrar a ralé, o viver sem teto, a ausência de família, a falta de amarras, a exclusão. Daí os pejorativos: "Moleque de rua", "Rua da amargura", "Colocar no olho da rua", "Ponha-se na rua!", "Rueiro", "O sujeito é mais deslavado que as pedras da rua", "Mulher da rua", entre outras.

A rua se mostrou, em certo imaginário, quase sempre como lugar do vício e do perigo. É de lá que a ameaça promete corroer a sociedade, com a peste, as epidemias, as doenças, a sujeira, os miasmas, todas as contaminações, a prostituição, a sexualidade, a mendicância, a incivilidade, a violência, a revolta, a insurreição e... a revolução!!!

Não é à toa que a rua moderna (o Bulevar seria para os modernistas a superação da rua) nasce com o urbanismo, pois os urbanistas lutaram incansavelmente, senão para acabar com a rua, pelo menos para domesticá-la, enquadrá-la, impor-lhe uma nova lógica, uma nova maneira de ser, evidentemente, menos porosa às paixões humanas e urbanas.

Conter a rua! Enquadrar a rua! Controlar seus excessos, limitar sua sociabilidade, são questões que atravessaram a rua moderna dos séculos XIX e XX e se derramam pela rua contemporânea, que vai refluindo cada vez mais diante da segurança que os lugares cercados e privados pensam oferecer.

Tal rua, qual cidade! O visgo da rua acaba grudando na cidade, fazendo esta à sua imagem e semelhança, pelo menos é isso que o imaginário dominante se conta do que foram os males das cidades modernas e quais são aqueles das metrópoles contemporâneas. Mostremos isso. 


\section{Cena I: RUA maldita}

Folheando os manuais de história da arte, sem grandes preocupações de historicizar a questão, o que vemos? De um lado, o bulevar largo e extenso, colmado de carruagens. Por ali desfila uma burguesia revelando o seu luxo e sua urbanidade cosmopolita. Tudo está em seu lugar, nada parece macular a sobriedade daquela calma urbana, tudo parece que foi feito para durar para sempre (Imagem 1). De outro lado, a rua com seus usos e abusos, plena de história, de gente, de acontecimentos, de rugas e rusgas. O traço límpido e agudo de Gustave Doré (1872) (Imagem 2) não deixa margens à dúvida: a rua londrina da primeira metade do século XIX é caótica, turbulenta, exasperante. Em nada lembra as paisagens bucólicas de um Turner, nem de um Constable, tampouco de um $\mathrm{Ca}$ naletto, quando pinta a rua veneziana.

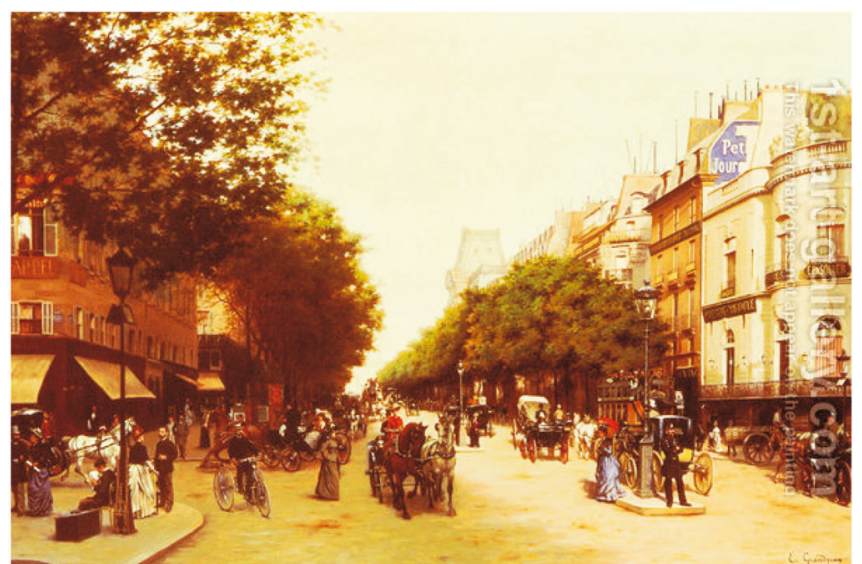

Imagem 1: Edmond G. Grandjean - Bulevar dos Italianos, 1890

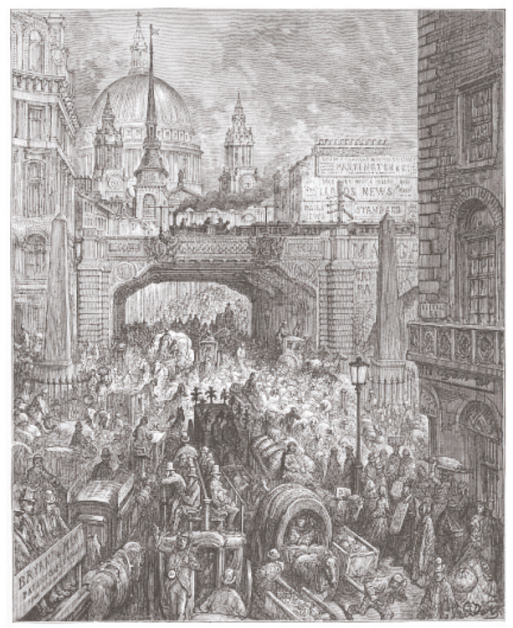

Imagem 2: Gustave Doré - Ludgate Hill, 1872 
Baudelaire (1995[1869], p. 136-137), em O spleen de Paris, no poema em prosa "Perda de auréola", já tinha alertado para o perigo do tráfego e da multidão na rua:

Agora há pouco, quando atravessava apressado o bulevar, saltando sobre a lama, através desse caos movente em que a morte chega a galope, por todos os lados ao mesmo tempo, minha auréola, num movimento brusco, escorregou da minha cabeça para o lodo do macadame [...].

A ameaça da rua se configura em várias representações artísticas e literárias. Em desenho feito por James Ensor, La mort purchassant les citoyens ou Le triomphe de la mort, de 1896, o autor nos mostra uma enorme foice, brandida por um esqueleto, pairando por sobre a cabeça da população de uma cidade, que desesperada, se comprime numa rua estreita. Parece ser o derradeiro fim da cidade. Uma imensa multidão, que se mistura indistintamente, procura fugir. A rua anuncia a morte.

Théophile Steinlein (1905) pinta, no seu quadro La manifestation, a presença popular na rua. Agitando bandeiras vermelhas, a massa, que não veio a passeio, politiza a rua, como a querer tomar a cidade. A rua tomada pelo povo não deixa espaço para mais nada que não seja a manifestação popular, que expulsa o cotidiano e convulsiona a cidade.

Jacob Steinhardt (1913) com a tela A cidade, dá-nos um painel grotesco e desesperado da rua. Ali as sombras parecem banhar de negro a vida dos passantes. A inexpressividade dos rostos aponta para um sem sentido de tudo. Uma espécie de luz ilumina vidas sem calor. A prostituta revela sua triste nudez à janela. A rua mais lembra um corredor, por onde se esgueiram seres que refugiam-se nas sombras, do que um lugar de encontro. Mais do que acolher, a rua parece expulsar as pessoas que por ela circulam.

Stanley Cursiter (1913), na pintura The sensation of crossing the street (Imagem 3) nos mostra a rua na qual tudo se mistura, na qual tudo é fluxo, na qual tudo se funde. Pessoas, ou parecem se desdobrar de outras pessoas ou parecem se fundir nos outros. Uma grande indistinção paira no ar: ser ou não ser na multidão, na confusão? A sensação de se atravessar uma rua é a da mistura, a de fazer parte daquilo tudo, de fazer parte da cidade, a de pertencer à multiplicidade de coisas e pessoas.

Em Berlim, Ludwig Meidner (1913) apresenta a rua sob o signo da ameaça (Imagem 4). Esta parece ser o ponto de convergência de todas as ameaças que pairam sobre a cidade. Há um nervosismo que promete mandá-la pelos ares. A rua assusta. 


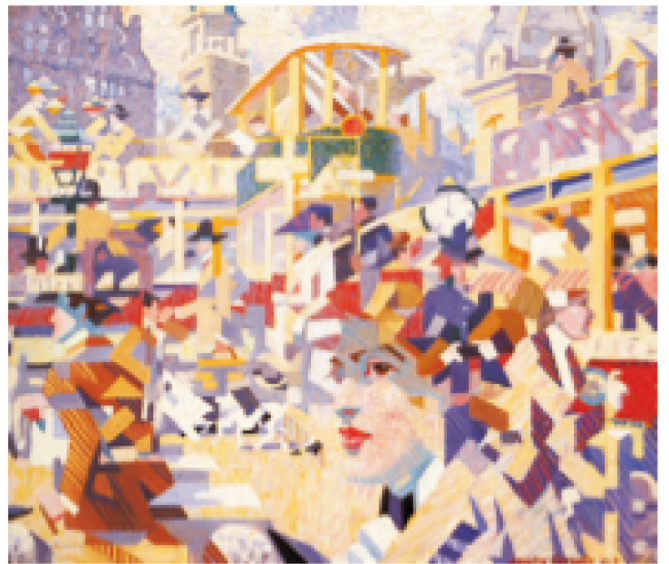

Imagem 3: Stanley Cursiter

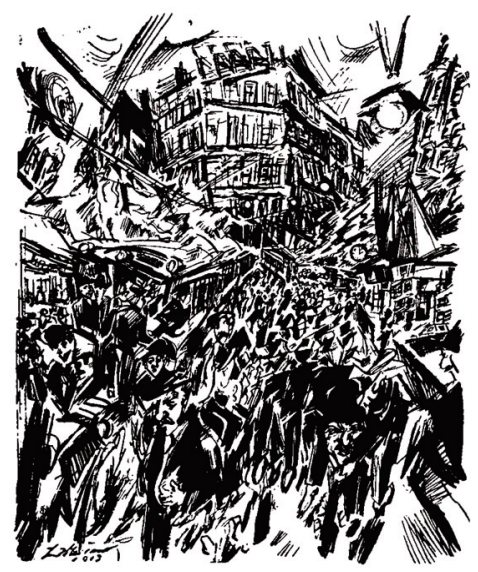

Imagem 4: Ludwig Meidner - Berlim,1913

The sensation of crossing the street, 1913

A rua prostituída, o comércio da carne humana, os cochichos, os olhares furtivos, a negociação do sexo, não deixam dúvidas de quanto a rua pode contaminar a cidade com sua sexualidade. Grosz nos mostra uma cidade desconfiada e assustada, ao mesmo tempo, com a proliferação de seus desejos. (Imagem 5)

O quadro Rua de Leipzig, de Albert Birkle (1923, Imagem 6), revela toda desesperança que a rua pode transmitir aos seres que por ela circulam. É noite na cidade, o cansaço, a desesperança, o cotidiano pesa sobre os transeuntes. Esses seres anônimos, sem olhos para deixar ver o que lhes vai na alma e obedecendo cegamente os fluxos da cidade, seguem seu irremediável destino. Eles apenas sobrevivem na cidade. Um velho, de olhos muito abertos, em primeiro plano, transmite todo o desespero que é estar nessa rua.

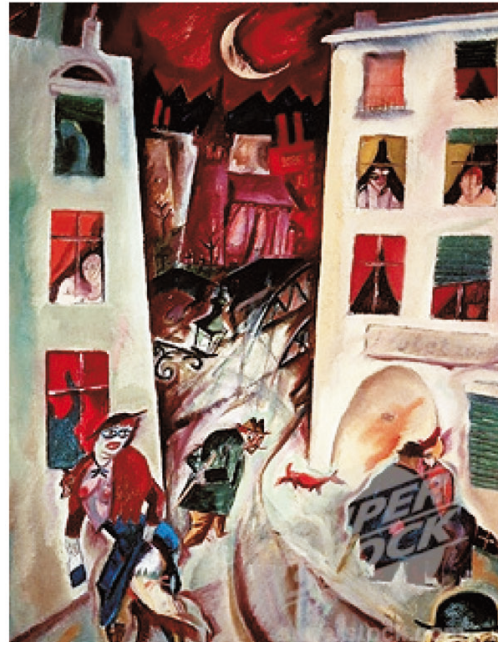

Imagem 5: George Grosz - A Rua, 1915

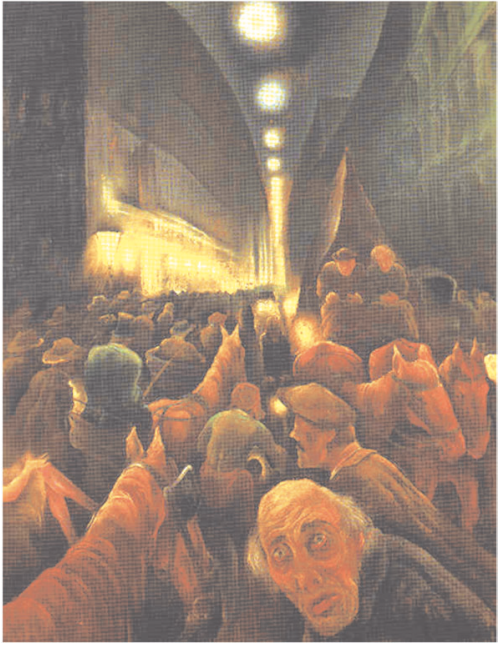

Imagem 6: Albert Birkle - Rua de Leipzig, 1923 
Nessa rápida amostragem do imaginário da rua vemos o quanto ela foi estigmatizada no momento mesmo da modernidade e da configuração da vida pública nas cidades. Nesse sentido, tudo aquilo que podia ter sido percebido como sinal de vitalidade urbana - a massa nas ruas exercendo seu direito à cidade e à cidadania - é vivido como sintoma de "problemas urbanos" para os quais as intervenções urbanísticas funcionariam como terapêutica. Dito de outra maneira, forja-se, na modernidade, toda uma percepção do que deva ser a cidade e que diz respeito à domesticação das paixões que pululam nas ruas. A convicção de que a rua é o lugar do conflito e, portanto, da desordem, funcionará como legitimação da necessidade de transformação desta, num espaço cada vez mais asséptico e que irá redundar em todo um repertório de imagens que estarão na base da cidade pós-moderna, ou seja, da cidade da funcionalidade e dos fluxos e que se recusa às inutilidades eróticas e poéticas, próprias de cidades que potencializam o encontro.

\section{CENA II: A RUA É o INFERNo}

Mas não é apenas na arte que podemos tomar o pulso e os significados das ruas. Se passarmos para outra linguagem, a da mídia contemporânea, igualmente constataremos o impulso de limpar a rua de uma história que se vai tornando indesejada.

Há alguns anos, quando foi inaugurado o shopping Morumbi em São Paulo, este fez estampar na revista Caras uma enorme propaganda de divulgação do evento. Tratava-se de um conjunto de cinco pares de fotos em que se procurava mostrar as excelências do shopping perante uma cidade já superada como lugar de ser e de estar. Nesse sentido, as fotos procuravam ressaltar, a partir de diferentes estéticas e éticas, atribuídas a cada um dos universos em questão, o contraste entre a cidade e o shopping. Assim, de um dos lados da página da revista, fotos em preto e branco da rua e da cidade paulista contrastavam com fotos coloridas, na página oposta, de algum aspecto da vida do shopping. Uma das fotos, por exemplo, revela um jovem negro à la rastafari (com tudo o que isso queira sugerir de estigmas) que vende suas bijuterias dispostas sobre um pano na calçada, que, num tom quase cinza, evoca um tempo que já passou e por isso mesmo produz uma certa sensação de decadência. Significativamente, o pano sobre o qual repousam as bijuterias se estende sobre um piso cujo desenho, não por acaso, simula o desenho do estado de São Paulo. Evidentemente, a imagem quer nos contar alguma coisa sobre esse lugar - São Paulo - que não deve mais ser identificado com a cidade real de São Paulo. De fato, fazemos tal constatação ao mirar a página oposta. Contrastando com o preto e branco sujo da foto, em imagem com um tom suavemente acinzentado que vai tendendo para o azul, belo jovem branco veste um muito bem cortado paletó no qual se ressalta elegante gravata, displicentemente pendurada no pescoço do bonitão, que combina soberbamente com sapato de cromo que aparece em detalhe. $\mathrm{O}$ instigante nessa imagem é que o jovem não parece estar identificado a nenhum lugar, porque não lhe circunda nenhuma paisagem. Ele pertence, pois, ao shopping, o novo lugar da cidade, que prescinde da própria cidade e certamente de suas ruas, que, por ainda serem doadoras de identidade, devem ser rifadas como marcas de um passado que não mais se deseja. 
Vira-se a página e, de novo, o contraste entre uma cidade descolorida que ficou no passado e o shopping de mil cores como promessa de futuro. Dessa feita, trata-se de fotografia em tom sépia, como a indicar um tempo que passou, que retrata dois velhos artesãos, que logicamente são insinuados como resquícios da cidade (Imagem 7). Na primeira foto, vemos um engraxate, com sua cadeira prá

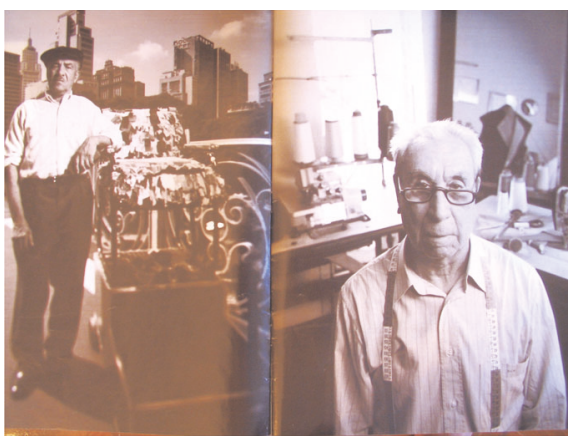

Imagen 7: Publicidade do Shopping Morumbi lá de démodé, e que tem como pano de fundo o cenário da cidade. Mas não se trata de um cenário qualquer da cidade. Lá estão dois ícones arquitetônicos da São Paulo do passado, o prédio déco do Banco do Estado de São Paulo e o Edifício Martinelli. A referência é absolutamente intencional e concisa de um tempo que já passou, logo, concluímos que o engraxate é um excesso, uma excrescência da cidade, fora de tempo e de lugar. A fotografia do segundo artesão revela um alfaiate em sua oficina de trabalho. Diferentemente do engraxate, o alfaiate não está na rua e o pano de fundo que emoldura sua imagem são os seus equipamentos de trabalho. A chave de interpretação dessa foto talvez seja o semblante interrogativo do homem, como a indagar se ele ainda tem lugar no mundo contemporâneo. Contrastando com o engraxate que atravanca a rua e remete para uma cidade que não existe mais, o alfaiate ainda tem alguma serventia nesse mundo. Mas percebemos, pelo seu olhar interrogativo, que é só uma questão de tempo... . Tempo! Essa é a questão que acentua o contraste entre as imagens da cidade e as imagens do shopping, pois tempo é história transcorrida, que é o mesmo que dizer que as coisas da cidade são de um tempo, tem um tempo, tem uma história... que diante do sem tempo e do sem história das mercadorias do shopping, acabou . Opondo-se e contrastando com os artesãos, figuram carnudos e sensuais lábios e o delicado colo de uma jovem. O chamado para o sensual e o erótico é inequívoco. Assim, aos carregados e interrogativos semblantes dos artesãos, os atraentes lábios femininos como a pedir beijos. Mas a história não acaba aí. Dialogando e contrastando com a imagem dos artesãos pontua uma segunda foto da moça (Imagem 8). Desta feita, seu corpo, quase por inteiro, toma conta da cena. Vestida com leve pano florido a modelo se revela absolutamente provocadora em sua pose. Diferentemente do alfaiate que parece se indagar se ainda tem lugar no mundo, a jovem, de-

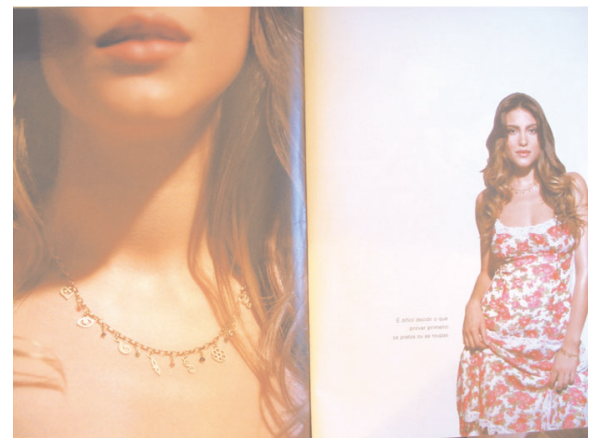

Imagen 8: Publicidade do Shopping Morumbi safiadoramente, deixa entrever que o mundo é dela, principalmente porque não há nenhuma cidade por trás dela, como pano de fundo, portanto, nenhuma história, nenhum tempo. É o novo mundo que se impõe ao velho mundo, superado e deca- 
dente. Longe dos tons cinza, preto e sépia, o que dá suporte à imagem feminina é uma parede branca com suaves tons de azul, no qual a ideia de leveza e de um "nada" sem história se impõem. Mas, como fica o shopping, que supomos, seja o ponto de convergência de todas essas imagens na formação de um imaginário que faça valer seu lugar na cidade, substituindo-a? O shopping tem potência para se impor à cidade?

A resposta a tal questão só vem quando viramos a folha e encontramos, agora ocupando uma mesma página, dividida ao meio, as fotos que explicam a que veio essa significativa propaganda. E aí a mensagem, embora expressa no seu avesso, é claríssima: a cidade é o Inferno! E o shopping? Ele é o lugar da fantasia, o lugar do desejo. Já me explico.

Estamos agora diante de uma fotografia marcadamente dramática (Imagem 9): uma menina negra brinca descalça de amarelinha na rua, claramente definida como rua de um bairro suburbano, pobre, violentamente marcado pelo tempo e carcomido pela história. A imagem não tergiversa, ela é contundente. A menina está na casa 7 se dirigindo para "fazer casa" no Céu. Ora, sabemos que a menina negra jamais irá para o céu, por sua condição mesma de negra, pobre e moradora da periferia. Essa

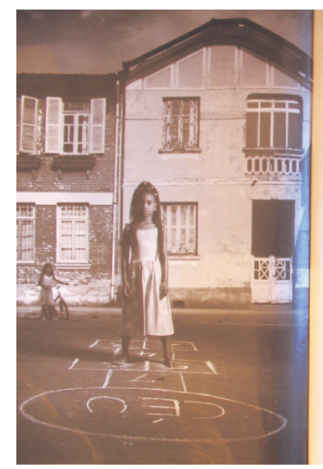

Imagem 9: Publicidade do Shopping Morumbi menina está condenada a morar na cidade. E aí define-se, finalmente, como uma linha de fuga, o contraste que aparecera anteriormente entre a cidade superada que emoldura a imagem do engraxate, a oficina do alfaiate e a parede branca que dá contorno à moça de lábios sensuais e pose provocadora. A parede branca que remetia a uma leveza e a um nada, agora se revela como oposta ao bairro suburbano com sua história de decadências. A parede branca fará o papel de algum Paraíso (o shopping?) a expulsar o Inferno para bem longe, para o subúrbio, talvez? Mais ainda, a página da foto em que aparece a menina brincando divide-se em duas. E o que aparece na outra metade da página? Uma "máquina de prêmios" colorida, dessas que existem em todos os shoppings, onde se põe uma moeda e se pinça um boneco de pelúcia. Por morar numa cidade descolorida, a menina da amarelinha jamais fisgará os bichinhos de pelúcia do shopping.

O desfecho da propaganda e o que dá sentido ao conjunto da narrativa são duas fotos. A primeira é da logomarca do shopping inscrita num verdadeiro obelisco plantado na frente dele e a segunda é a foto de uns dizeres em que se lê: "Morumbi Shopping. Tão completo como São Paulo, que tem até um obelisco".

A associação entre o shopping e a cidade não é, portanto, fortuita. Aliás, a primeira imagem do conjunto de fotos que perfazem a "história" contada pela propaganda do shopping é uma foto aérea da cidade na qual se divisam, em primeiro plano, dois ícones da arquitetura moderna de São Paulo: o Copan e o 
Edifício Itália. A foto indica que o que se vai narrar tem a ver com cidade. Emblematicamente, contudo, a cidade vai saindo de cena e o shopping vai-se materializando, para, no final, se estabilizar como uma verdadeira epifania, na forma de um obelisco que afronta, enfrenta e indaga a cidade. Tendo atravessado toda a narrativa publicitária a impossível composição shopping/cidade leva o leitor da revista a ter que escolher entre um e outro, entre a imundície das ruas e o asséptico do shopping, entre o Inferno e o Paraíso.

\section{CENA III: A RUA COMO LIXEIRA DA CIDADE}

Se dissermos que no Brasil a rua sempre foi percebida como lixeira da cidade isso não deve causar estupor em ninguém. Entre nós, desde sempre, a rua foi e continua sendo terra de ninguém, para onde atiramos tudo aquilo que, já usado, queremos descartar. Assim, o esgoto, as águas servidas e o lixo colonial, assim o desprezo republicano pela rua, lugar de malandros, vadios, preguiçosos e, principalmente, dos "homens perigosos". Na história brasileira o privado sempre fez sombra ao público, seja a Casa Grande sobre a Senzala, seja o Sobrado sobre o Mocambo. Nesse sentido, somos herdeiros de uma tradição de canibalização da vida pública e da coisa pública. Os jornais noticiam diariamente desde os maus tratos à cidade (sujeira, depredação, roubo dos bens públicos, apropriação e utilização ilegal do espaço público) à corrupção e apropriação indevida de seu patrimônio público. Podemos mesmo afirmar que uma parte da "riqueza urbana" foi e ainda é obtida graças à dilapidação dos bens comuns, via mercado fundiário/mercado imobiliário, serviço de distribuição de infraestrutura, sistema de transporte etc. Não é de estranhar, pois, que mesmo no século XXI, o público seja o lugar em que o interesse privado vai-se abeberar e encher a burra. Não é de estranhar, tampouco, que o espaço público continue sendo uma espécie de terrade-ninguém, ou seja, o lugar mais frágil, descuidado e desprotegido da cidade.

A cena obscena em questão foi vivida por seus protagonistas como uma "divertida e engraçada brincadeira". Trata-se de um grupo de jovens, mas não só jovens, muito ricos e por isso, supomos, com acesso a todos os requintes da civilização e da cultura, que entediados do seu cotidiano resolveram se divertir atirando ovos (podres e sãos) da janela de um desses apartamentos de milhares de dólares, de frente para o mar, na zona sul do Rio de Janeiro. Toda a brincadeira, que foi gravada por um deles, consistia em atirar os ovos nos transeuntes que passavam desavisados e depois se esconder, morrendo de rir, com o espanto daqueles que eram atingidos, inclusive, um carro da polícia.

A obscenidade da cena diz respeito à ruptura do regime de visibilidade da cena urbana, que supõe troca de olhares, identificação e reconhecimento do outro e a confiança de que todos estamos sob o regime da luz, no qual todos "aparecem" diante do social. Aqueles que cada vez mais prescindem da cidade, aqueles que teatralizam suas vidas nos espaços privados jazem na obscuridade do esconderijo privado operando movimento contrário ao da cena, produzindo aquilo que não deve 
ser visto - a obs-cena. Aqueles que mais precisam usar a rua, aqueles que no seu ir e vir de sobrevivência e usos da urbe, "aparecem" na cidade, justamente, quando estão na rua, para eles a cena urbana é incontornável, assim como a cidade.

Mais ainda, a cena é obscena porque diz respeito a um gozo escondido - que desliza da cena pública para a privada - no qual não se supõe o outro, ou seja, o outro só entra em cena como objeto, como vítima.

\section{CENA IV: RUAS DA DESORDEM}

Nesta cena a rua é cenário, mas também o signo do desprezo pela cidade. Trata-se de uma peça publicitária que foi fartamente veiculada pela televisão e dizia respeito a certa marca de carro. Estabelecendo uma oposição entre carro/ privacidade/ordem e espaço aberto/rua/espaço público/caos, a peça publicitária nos faz ver um famoso ator que interpreta o policial Jack Bauer, um daqueles heróis que faz de tudo para salvar a América do terrorismo, ou seja, do outro, que não é americano. Jack Bauer está ao volante e tem a seu lado uma bela mulher. A cena se passa no coração nervoso de São Paulo por onde o carro de Bauer desliza gostosamente. Acontece que, surpreendentemente, as ruas da imensa metrópole estão vazias. Logo saberemos por que! O carro acelera e viv'alma desponta, a máquina parece se deliciar por roçar seus pneus por uma paisagem tão vazia, como se dispondo a ser conquistada por Jack e seu carro. Jack olha de maneira interrogativa para sua gata. Em dado momento o herói pára o carro e abre a porta. Nesse momento o mundo parece vir abaixo. Um barulho ensurdecedor e o caos total se impõem. São carros a se chocar, motos a voar junto com seus motociclistas, que se soma à confusão de britadeiras, obras, brigas, ou seja, o cotidiano das ruas, a realidade da cidade, a sensação de caos. Diante de tal situação, Jack Bauer fecha a porta do carro e imediatamente a paz se impõe. Após o que, ele sorri para sua acompanhante e confiantemente diz: "It's fine". O carro se afasta deixando para trás a desordem total. Nesse momento, a cidade começa a desmoronar (EURO/RSCG Brasil, online).

O que esta propaganda estaria vendendo, então? Várias coisas, entre elas, o carro. Deixando esse objeto de desejo em segundo plano, o que vem para primeiro plano e explica as ruas da grande metrópole, do começo do anúncio, vazias? A privacidade, o isolamento, a calma, a ordem. Em uma palavra, não há pervasão entre o interior do carro e o exterior, ou seja, a rua com seus alaridos não penetra no isolamento total do carro. Não há, sobretudo, porosidade entre o privado e o público. O que nos permite concluir que, mesmo na cidade, sugando as ruas da cidade, o carro anunciado permite ao seu feliz proprietário se isolar dela, ignorála. Em outras palavras o carro se impõe como uma imagem de proteção contra a cidade. Ele está na cidade, mas ignora a vida urbana, para se lançar num delírio de isolamento, individualismo e subjetividade. A rigor esse é o tema da propaganda: a subjetividade desse homem contemporâneo, que se faz às expensas do social, às expensas da relação com outro, às expensas da cidade. Porque isolado no seu carro, sugere a propaganda, esse ser se constitui como sujeito. Mas não mais sujeito, ser de uma cidade, cidadão, mas uma espécie de essência, de natureza, 
dada, não mais pelo social, mas dada pela propriedade de uma mercadoria que tem o poder de isolar o indivíduo da contaminação das ruas. Por que outro motivo a propaganda termina com o carro deixando o caos da rua de lado enquanto a cidade desmorona por trás?

\section{Cena V: homens InVISíveis CAMINHAM PELAS RUAS}

Viaduto do Chá. São Paulo. Noite. Pedestres cruzam o viaduto. Cada qual vai ensimesmado consigo mesmo. Escuridão. Sombras. A meio caminho, no viaduto que atravessa o Vale do Anhangabaú, dois enormes fachos de luz. 12 mil watts. Os fachos cortam a passarela. É noite em São Paulo. Figuras fugidias brilham sob a iluminação intensa. 15 segundos de "fama". Seres invisíveis brilham por segundos. Quem é vivo sempre aparece. Por segundos. Na cidade. Silhuetas. Homens anônimos. Só existem enquanto brilham. Sob a luz intensa. "Detector de Ausências" (figura 10). Detectar ausências na cidade. Estar na cidade. Invisibilidade. Homens invisíveis. Na rua. Ninguém os olha. Ninguém os vê. Eles existem na rua? Anonimato. Quem tem direito à cidade? Que ausências a luz captou? Que invisibilidades ela realçou?

A rua dos acontecimentos. A rua sem acontecimentos. A rua vazia. Os homens invisíveis fora do facho de luz.

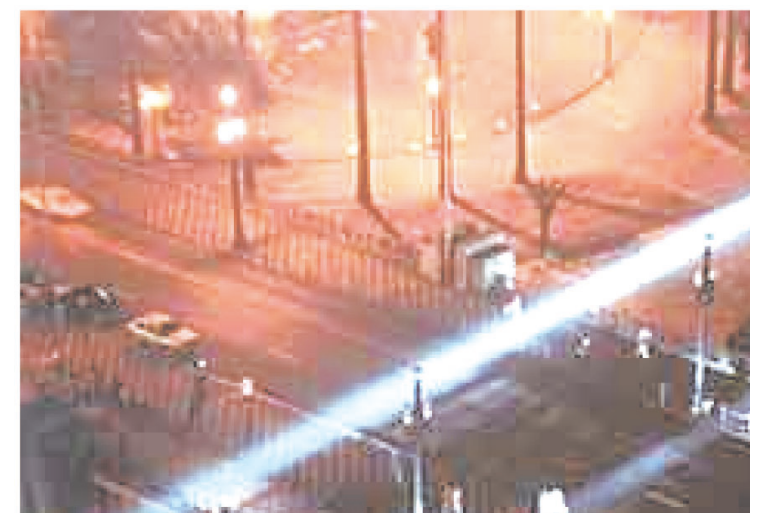

Viaduto do Chá. São Paulo. Noite. A luz apagou.

Ninguém vê ninguém.

São Paulo cega! 


\section{Cena VI: o deSEJo SOlto nAS RUAS}

Jenny Holzer, artista americana que "planta" painéis luminosos nas ruas e empenas de prédios, um dia instalou um desses painéis num prédio por onde toda a cidade passava na hora de ir para o trabalho e na hora de voltar para o lar. De manhã, na alacridade da luz poucos se davam conta do que estava escrito no painel. Mas, no final do dia, já escurecendo na cidade, as letras luminosas se destacavam. E o que a artista havia semeado em solo urbano tão pouco propício a floradas?

Holzer (apud KUSTER, 2006) incendiou o imaginário da cidade com uma simples frase: "PROTEJA-ME DO QUE EU QUERO"2 (figura 11). Que podemos, levando às últimas consequências a incitação da artista para sacudir a rua, traduzir por: "PROTEJA-ME DE MEU DESEJO".

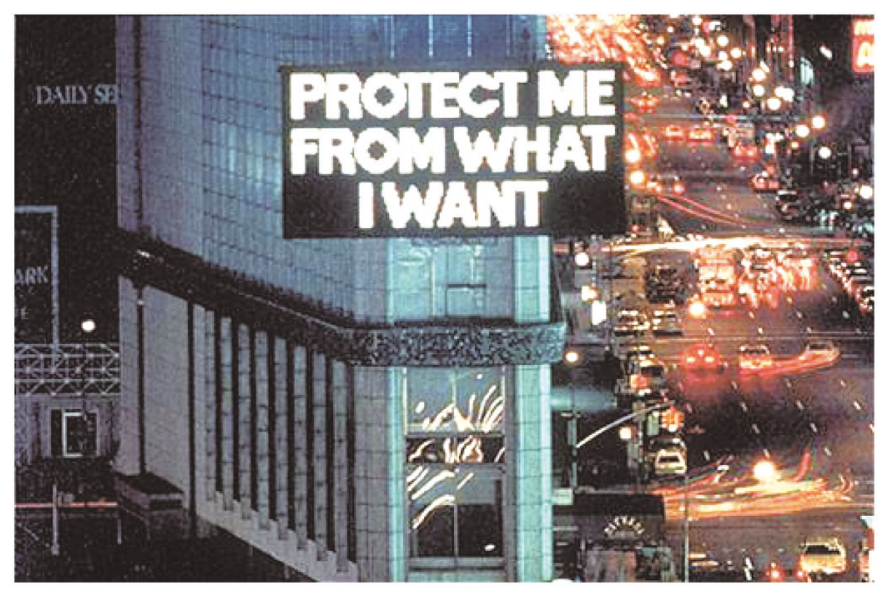

Imagem 11 - Jenny Holzer - Truisms, 1985.

O desejo solto nas ruas... O que seria isso? Depois disso a cidade teria continuado a ser a mesma?

\section{Cena VII: SOltos E VAGANdo PELAS RUAS}

O filme Lost in Translation (2003 - br: Encontros e desencontros), exemplar da experiência urbana vivida em um não-lugar, um hotel cinco estrelas em Tóquio, retrata a melancolia de personagens que experimentam a cidade olhandoa do alto do prédio do hotel. Enquanto estão "protegidos" pelo hotel nada lhes acontece, nada os afeta.

Um homem maduro e casado há uma eternidade e uma jovem mulher recém-casada se conhecem no hotel. Tornam-se muito amigos e experimentam o tédio de estarem numa cidade desconhecida à qual nunca chegam, preferindo o aconchego conhecido, prometido pelo quarto do hotel. Enquanto esperam o tempo passar divisam uma Tóquio ao longe, pano de fundo para suas solidões, tédios 
e bate-papos intermináveis. Enquanto estão no hotel e a cidade é puro cenário ao longe, nada lhes acontece e nenhuma proximidade amorosa é experimentada entre os dois. Mas soltos e vagando pelas ruas da cidade os personagens são tocados pelo acontecimento urbano e isso os transforma. E o que descobre o casal? Que a cidade pulsa fora do hotel! Afetados pela cidade, o homem e a mulher passam a descobrir seus afetos e a reconhecer que o encontro com o outro é uma condição que só a porosidade da cidade pode dar. "Perdidos na tradução", segundo a tradução literal do título do filme, os personagens precisam aprender a traduzir a cidade e parecem só poder entrar em contato com seus afetos quando ousam fazêlo, saindo do quarto do hotel, perambulando pelas ruas e se relacionando com a vida local. O encontro na cidade, o reconhecimento do outro, é a espora do amor. A cidade possibilita, desperta o amor, pelo menos no filme.

Que o diga o personagem de Baudelaire (2006[1861]) de "A uma passante". Que o digam os personagens de Lost in translation (2003), que só se descobrem apaixonados, na rua, no meio da multidão.

\section{CENA VIII: QUANDO A RUA É FlUIDA E O CORAÇÃo ESTÁ ENGARRAFAdo}

Recente filme brasileiro, Não por acaso (2007), nos fala da rua a partir da perspectiva dos engarrafamentos de São Paulo. Trata-se de um engenheiro que defendeu seu mestrado no exterior, em Engenharia do Tráfego, e vai trabalhar no controle do caótico fluxo de veículos da cidade, diante de enormes telas que monitoram o movimento de rua. Usando de toda uma racionalidade que se quer científica, o engenheiro se mostra uma espécie de "deus da rua", já que, graças à sua lógica, ele consegue dar um mínimo de fluidez ao tráfego. Só não consegue fazer com que seus afetos pessoais fluam, na cidade. Seu coração está permanentemente engarrafado, bloqueado e sua cidade (seu mundo interno) constantemente vazio, pois que ele, em sua solidão, transita apenas entre seu apartamento e a sala de gerência do trânsito. Esse gerente do trânsito infernal da gigantesca cidade não sabe gerenciar o amor de uma filha adolescente, de uma relação fracassada, e corre o risco de vê-la partir para uma longa temporada no exterior.

Aquele que conhece todos os fluxos possíveis para fazer a rua fluir não tem a mínima ideia da vida que nela pulsa. E, no entanto, por uma circunstância dos afetos esse "dono da rua" é levado a baixar a ela e usando de toda lógica de um especialista em trânsito, bloqueia o fluxo da cidade para reter o tráfego e impedir a chegada do carro que leva sua filha para o aeroporto e assim recuperar o objeto de seu amor, que lhe fugia na fluidez do trânsito da rua.

\section{CENA IX: SOLVITUR AMBULANDO... NA RUA}

Ver a rua sob o signo da negatividade e mesmo do desprezo não significa dizer que os artistas que a representam a desprezem. Em sua sensibilidade e capacidade de percepção o artista consegue captar sentidos e sentimentos que evolam da rua traduzindo-os para nós e revelando a história que cada sociedade se conta sobre seu ser e sobre o seu estar na cidade. 
Metonímia da cidade, a rua traduz o mundo urbano e nos conta muito das formas da sociabilidade e da urbanidade de cada cidade. Assim, podemos afirmar dessa rua: tal rua qual cidade. Nesse sentido o conto de Rubem Fonseca (1994, p. 11-50) "A arte de andar nas ruas do Rio de Janeiro", traduz e atualiza em toda a sua radicalidade o universo de uma cidade à beira do abismo. Uma cidade que oscila entre a potência de comungar com seus cidadãos uma vida pública e uma cidade que já não tendo o que contar para os seus "admite" que cada um se conte sua história sem que qualquer intersubjetividade dê limite a pretensas trajetórias urbanas que apostam que a cidade é apenas um trampolim para suas conquistas narcísicas.

Nesse sentido, Rubem Fonseca faz com que seu personagem, que quer escrever um livro sobre "a arte de andar nas ruas do Rio", se empenhe por "encontrar uma arte e uma filosofia peripatéticas que o ajudem a estabelecer uma melhor comunhão com a cidade. Solvitur ambulando" (FONSECA, 1994, p. 11) Ora, quem diz filosofia peripatética refere-se a ensinar enquanto se caminha e se esse ensinamento se materializa num solvitur ambulando (resolver os problemas conversando enquanto se caminha) não tenhamos dúvida, então, que Fonseca está convocando os fantasmas da Pólis, as sombras generosas da experiência da vida pública de Atenas, para que a cidade recupere sua função pedagógica e ilumine os passos de seu personagem na procura de uma melhor comunhão com a cidade.

Na rua de Fonseca não cabem bacanas, não cabem nem famosos, nem formosos. Não cabem shoppings, condomínios, nem não-lugares. Mas cabem, sim, putas, andarilhos, flâneurs, mendigos, malucos, todos os deserdados da cidade. Na rua de Fonseca cabe uma poética, cabe uma erótica. Naquela rua cabe a sociabilidade, pois só ela é capaz de acolher o dissenso.

\section{OH! Sim, AS RUAS TÊM ALMA}

É assim que João do Rio (1987, p. 7), o grande cronista carioca do começo o século XX, se refere à rua em crônica no livro $A$ alma encantadora das ruas. Para João do Rio, embora existam ruas ambíguas, trágicas, depravadas, infames, medrosas, covardes, elas tem uma alma. Segundo o cronista, as ruas das grandes cidades têm o poder de criar o tipo urbano, de plasmar a moral dos seus habitantes, inocular-lhes gostos, costumes, hábitos, modos, opiniões. E mais do que isso, as ruas para ele, são entes vivos, pensam, têm ideias, filosofia e religião (RIO, 1987, p. 7-12).

Firme em sua crença no poder da rua, João do Rio (1987, p. 19) concluiu: "Talvez que extinto o mundo, apagados todos os astros, feito o universo treva, talvez ela ainda exista e os seus soluços sinistramente ecoem na total ruína, na rua das lágrimas, rua do desespero- interminável, rua da Amargura[...]”.

A maldição que recaiu sobre as ruas vem, competentemente, corroendo a sua alma, seja na sua condição de fundamento da vida pública, seja na sua vertente da sociabilidade; quer na vertente da ação cidadã, quer na dimensão amorosa; seja na modernidade, seja na contemporaneidade. Tal maldição, contudo, não é 
fruto das artimanhas nem de bruxas, nem de feiticeiras e muito menos vem dos confins obscuros da sociedade. Ao contrário, tal elaboração imaginária nasce ali mesmo onde a sociedade contemporânea tem inventado fábricas sem trabalhadores, comunicação sem corpo, prazeres sem toque, cidades sem hospitalidade e onde os cidadãos são transformados em consumidores.

A rua maldita é fruto do mesmo imaginário que inventa condomínios fechados, ruas exclusivas, bairros isolados, casas fortificadas, cidades muradas.

Apesar de estigmatizada, entretanto, a rua é ainda a única possibilidade de a cidade continuar a ser o lugar do convívio, da diferença, da hospitalidade, do acolhimento, e, no limite, da vida em sociedade. Livre do preconceito a rua é um convite à retomada da cidade, pois, é justamente ali que esta atualiza seu repertório. É o que se observa em diferentes representações sobre a experiência urbana dos últimos anos, numa espécie de disputa de hegemonia entre diferentes discursos que apregoam seja o terror, seja a possibilidade da festa, na rua.

Se abrirmos o jornal-nosso-de-cada-dia e mesmo se atentarmos para o noticiário das grandes redes de televisão, não mais saímos à rua. Mas, se ainda assim insistirmos em provar desse veneno, talvez devêssemos, num primeiro momento, aguçar nossos ouvidos, mais do que abrir nossos olhos. E aí talvez pudéssemos ouvir uma canção que canta:

Eu vou à cidade hoje à tarde

Tomar um chá de realidade e aventura

Porque eu quero ir pra rua

Eu quero ir pra rua

Tomar a rua

Não mais

Não mais aquela paúra

De ser encarcerada pra ficar segura

Já cansei de me trancar

Vou me atirar

Já cansei de me prender

Quero aparecer

Aparecer, aparecer

Eu sou da cidade e a cidade é minha

$\mathrm{Na}$ contramão do surto de agorafobia

Agora eu quero ir pra rua

Porque eu quero, quero ir pra rua

Levar

A dura de cada dia

Sair da minha laia, chegar na sua 
Eu vou à cidade sem compromisso

Tomar um chá, um chá de sumiço no olho da rua

Porque eu quero ir pra rua

Eu só quero ir pra rua

Olhar a rua

Tomar, bem que se podia, ar fresco

Topar Banksy a pintar afrescos

Já cansei de me trancar

Vou me atirar

Já cansei de me prender

Quero aparecer

Aparecer, aparecer, desaparecer [...].

(TOLLER; CORINGA, 2007)

Caro leitor, afundar na poltrona é algo capaz de abolir a cidade e nos ofertar a vida natural, aquilo que os gregos chamavam de zoé, e que exprime o simples ato de viver fisicamente, comum a todos os seres vivos. Afundar no mundo, caro, é sair do primado da vida natural e tentar remontar à transformação e à decadência do espaço público, para o que Hannah Arendt já alertava há mais de 50 anos.

A escolha é sua...

\section{Notas}

${ }^{1}$ Trata-se de uma instalação artística chamada "Detector de Ausências", realizada no Viaduto do Chá, em 1994 para o evento Arte e Cidade. Ver: PEIXOTO, N. B.- Paisagens urbanas. São Paulo: Senac, 1994, p.49 a p. 53.

${ }^{2}$ Ver KUSTER, E..O Preço da Cidade: as dificuldades da convivência urbana contemporânea no espelho das representações artísticas. Vitória: fotocópia, 2006.

\section{REFERÊNCIAS}

BAUDELAIRE, C. O spleen de Paris (1855-1867). Rio de Janeiro: Imago, 1995. . As flores do mal (1861). São Paulo: Martin Claret, 2006

BIRKLE, A. Leipziger Straße. 1923. Pastell. $96 \mathrm{~cm}$ x 67,5 cm.

CURSITER, S. The sensation of crossing the street. 1913. Oil on canvas.

DORÉ, G. Ludgate Hill: a block in the street. 1872. Wood engraving.

ENSOR, J. Le triomphe de la mort. 1892. Huile sur toil, $155 \mathrm{~cm}$ x $150 \mathrm{~cm}$. .La Mort poursuivant le troupeau des humains. 1896. Etching and drypoint,

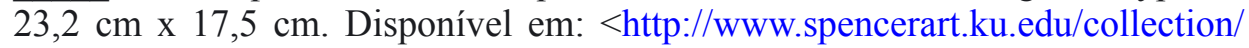
print/ensor/4.shtml>. Acesso em: 12 maio 2009

FONSECA, R. Romance negro. São Paulo: Companhia das Letras, 1994. 
GRANDJEAN, E. Le boulevard des italiens. 1890 . Oil on canvas. $81 \mathrm{~cm}$ x $60 \mathrm{~cm}$. GROSZ, G. Die Straße. 1915. Öl auf Leinwand. $46 \mathrm{~cm}$ x $36 \mathrm{~cm}$.

HOLZER, J. Protect me from what I want. New York City. 1985. Painel luminoso.

JACK Bauer on Citroën C4 Pallas Tv Comercial. São Paulo: EURO/RSCG Brasil, 2007. Disponível em: <http://www.youtube.com/watch?v=GrYzJgTbF4Q>. Acesso em: 12 maio 2009.

KUSTER, E. O Preço da Cidade: as dificuldades da convivência urbana contemporânea no espelho das representações artísticas. Vitória: [s.n.], 2006.

LOST in translation. Direção: Sofia Copolla. Produção executiva: Francis Ford Copolla. Intérpretes: Scarlett Johansson; Bill Murray; Akiko Takeshita e outros. Roteiro: Sofia Copolla. Los Angeles: Focus features c2003. 1 DVD (102 min), color.

MANO, R. Detector de ausências. São Paulo. 1994. 1 original de arte. Instalação luminosa para o evento Arte e Cidade.

MEIDNER, L. Berlim. 1913. Xilografia.

NÃO por acaso. Direção: Philippe Barcinski. Produção: Fernando Meirelles, Donald Ranvaud, Bel Berlinck, Cláudia Büschel, Bel Berlinck, Andrea Barata Ribeiro. Intérpretes: Rodrigo Santoro; Leonardo Medeiros; Letícia Sabatella Branca Messina e outros. Roteiro: São Paulo: Fox, c2007. 1 DVD (102 min), color.

PEIXOTO, N. B. Paisagens urbanas. 3. ed. São Paulo: Senac, 1994.

PORTELLA, E. Educação pela cidade. Revista Tempo Brasileiro, Rio de Janeiro, n. 120, p. 109-114, jan./mar. 1995.

PUBLICIDADE do Shopping Morumbi. [1982]. 10 fotografias. Fotos publicadas na revista Caras.

RIO, J. A alma encantadora das ruas. Rio de Janeiro: Biblioteca Carioca, 1987.

STEINHARDT, J. The city. 1913. Oil on canvas.

STEINLEN, T. La Manifestation. 1905. Huile sur toile.

TOLLER, P.; CORINGA. Eu quero ir pra rua. In:

Só Nós. Intérprete: Paula Toller. Rio de Janeiro: Warner Music Brasil, p2007. 1 CD. Faixa 10.

Recebido em: junho de 2009

Aceito em: agosto de 2009 